UDC 539.3

\author{
S. I. Trubachev, O. N. Alekseychuk
}

\title{
THE CALCULATION OF THE STRESS-STRAIN STATE OF THE FRONT LANDING GEAR TRANSPORT AIRCRAFT
}

\section{Introduction}

There are special requirements for reliability and durability is imposed to aircrafts that are due to the need to ensure safety in difficult conditions.

The problem of calculating the stress-strain state of transport aircraft landing gear elements are relevant because they work under of variables loads in time. To solve the problem of determining the stress-strain state of the front landing gear rack the analytical methods are inefficient by reason of complex geometry, so it is advisable to apply numerical simulation [1]. This approach is particularly important in cases of new materials and technologies.

Currently, the main method of determining the stress-strain state is finite element method, which is implemented in computer systems of engineering analysis. One of them is a system ANSYS, that allows with a high level of accuracy to determine the characteristics of the stress-strain state of structural elements in elastic and elastic-plastic calculations. The modeling and calculation object is the front rack of landing gear of the aircraft.

\section{Formulation and solution of the problem}

To construct a three-dimensional model we used the tetrahedral finite elements (fig. 1)

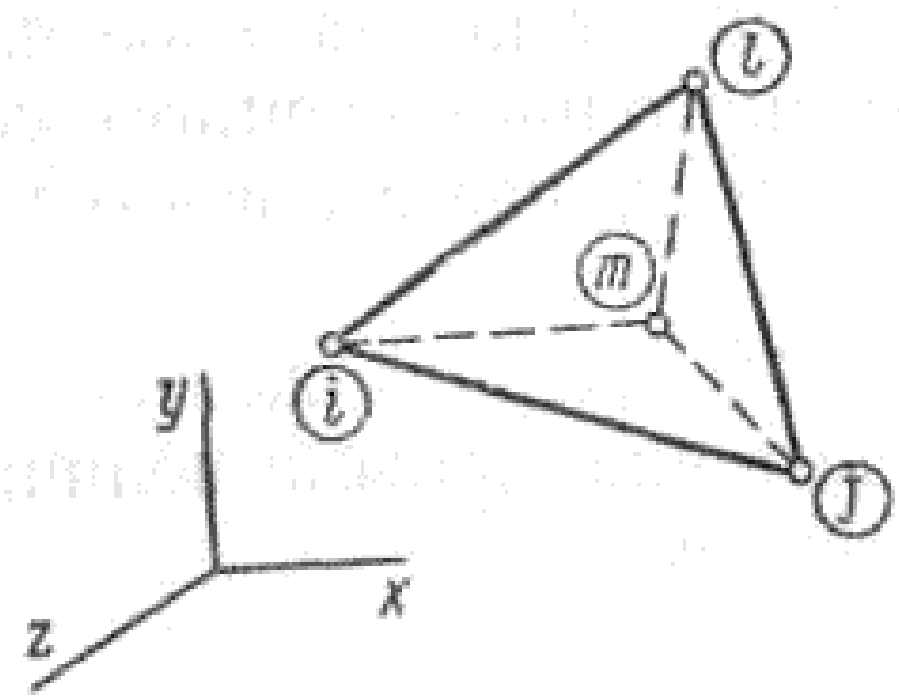

Fig. 1. The tetrahedral finite element 
The linear displacement field is given in the form:

$$
\begin{aligned}
& u_{x}=f_{1}+f_{2} x+f_{3} y+f_{4} z ; \\
& u_{y}=f_{5}+f_{6} x+f_{7} y+f_{8} z ; \\
& u_{z}=f_{9}+f_{10} x+f_{11} y+f_{12} z,
\end{aligned}
$$

where $f_{1} \ldots f_{12}$ - are the arbitrary constants.

When we equating the $u_{x}, u_{y}, u_{z}$ at key points to the relevant nodal displacements can be expressed through the constant nodal displacement $v^{e}$ and get dependence as $u=\alpha v^{e}$.

All six components of deformation are taken into account in of the threedimensional case. Using geometric equation, we write the matrix deformation as:

$$
\{\varepsilon\}=\left\{\begin{array}{l}
\varepsilon_{x} \\
\varepsilon_{y} \\
\varepsilon_{z} \\
\gamma_{x y} \\
\gamma_{y z} \\
\gamma_{z x}
\end{array}\right\}=\left\{\begin{array}{l}
\frac{\partial u}{\partial x} \\
\frac{\partial v}{\partial y} \\
\frac{\partial u}{\partial y}+\frac{\partial v}{\partial x} \\
\frac{\partial v}{\partial z}+\frac{\partial w}{\partial x} \\
\frac{\partial w}{\partial x}+\frac{\partial u}{\partial z}
\end{array}\right\}
$$

In the general case stress matrix column is written as:

$$
\{\sigma\}=\left\{\begin{array}{l}
\sigma_{x} \\
\sigma_{y} \\
\sigma_{z} \\
\tau_{x y} \\
\tau_{y z} \\
\tau_{z x}
\end{array}\right\}=[D]\left(\{\varepsilon\}-\left\{\varepsilon_{0}\right\}\right) .
$$

$\left\{\varepsilon_{0}\right\}$ - are the temperature deformation, which in this case are not captured.

Elasticity matrix for isotropic material has the form: 


$$
[D]=\frac{E(1-v)}{(1+v)(1-2 v)}\left[\begin{array}{cccccc}
1 & \frac{v}{1-v} & \frac{v}{1-v} & 0 & 0 & 0 \\
\frac{v}{1-v} & 1 & \frac{v}{1-v} & 0 & 0 & 0 \\
\frac{v}{1-v} & \frac{v}{1-v} & 1 & 0 & 0 & 0 \\
0 & 0 & 0 & \frac{1-2 v}{2(1-v)} & 0 & 0 \\
0 & 0 & 0 & 0 & \frac{1-2 v}{2(1-v)} & 0 \\
0 & 0 & 0 & 0 & 0 & \frac{1-2 v}{2(1-v)}
\end{array}\right] .
$$

$E$ - is the elastic modulus the material, $v$ - is the Poisson ratio.

The calculation of landing gear structural elements on finite element method was implemented using the software complex ANSYS [2]. The geometric model is shown in fig. 2.

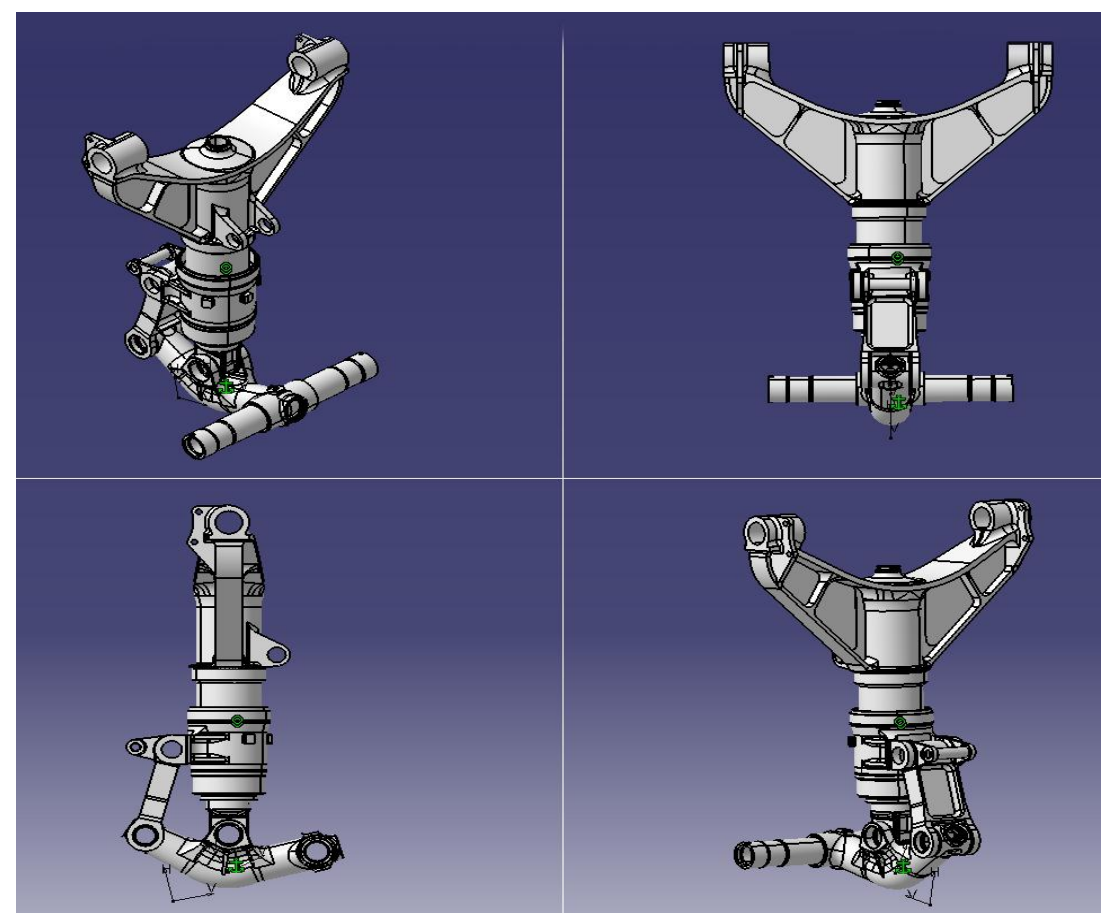

Fig. 2. The geometric stands model

The structural elements of the front landing gear were imported from the geometric patterns into the program which created calculation model for the calculation by the finite element method. The finite - element model is shown in fig. 3.

As a result of the calculation the equivalent stress were determined by criterion for Misses, and the most dangerous places were found (fig. 4.) 


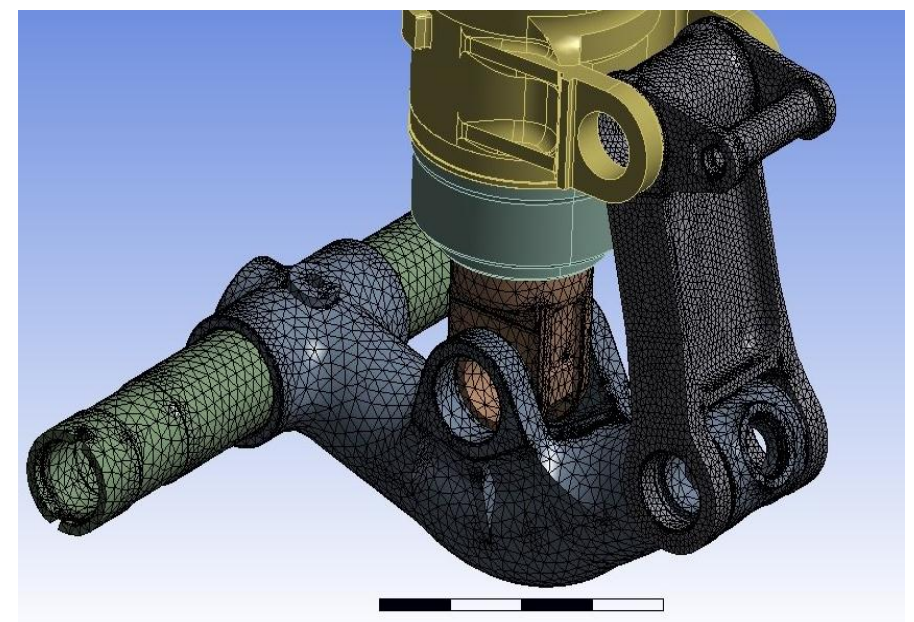

Fig. 3. The finite - element model

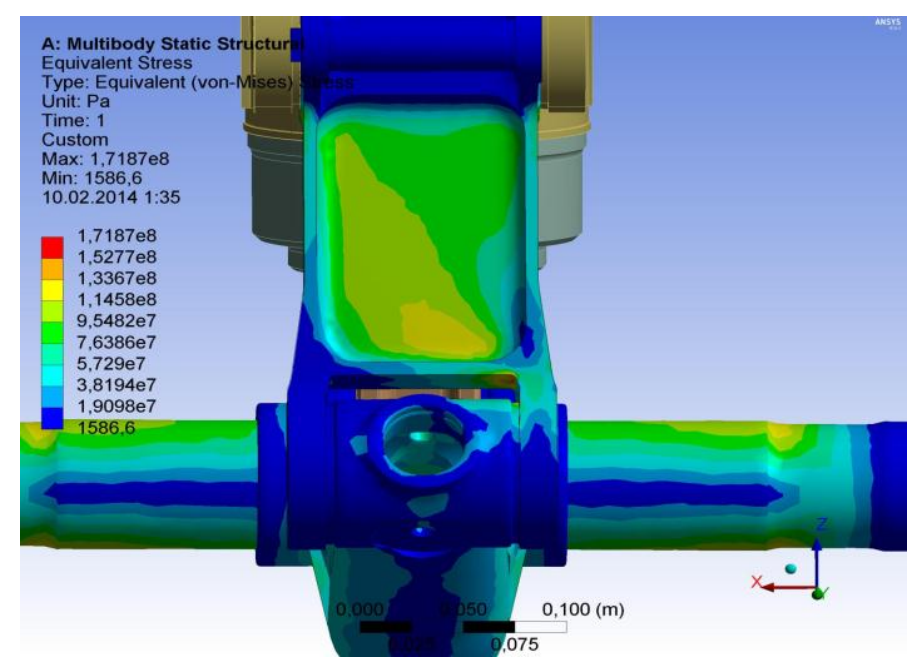

Fig. 4. The fields of stresses (PA)

\section{Conclusions}

The most dangerous places in terms of stress were found as a result of analysis the stress-strain state of the front landing gear stands using the method of finite elements. This made it possible to optimize the construction. The ANSYS system allows determining the characteristics of the stress-strain state of structural elements in elastic and elastic-plastic calculations with a high accuracy.

\section{References}

1. Цыбанева Г.В. Анализ особенностей нагружения элементов опоры шасси самолета с целью их учета при оценке несущей способности конструкции // Г. В. Цыбанева, М. А. Агеев, Р. В. Титенков/ Проблемы прочности, 2008, № 4.

2. Басов K. A. ANSYS: Справочник пользователя. - М.: ДМК Преcс, 2005. - 640 c. 